\title{
THE EFFECT OF SMARTPHONE TECHNOLOGY DEVELOPMENT ON STUDENT MORALITY
}

\author{
Didin Komarudin \\ Adnan \\ Asrizal A. Upe \\ Faculty of Ushuluddin UIN Sunan Gunung Djati Bandung \\ e-mail: pakdidin76@gmail.com
}

\begin{abstract}
:
This research is formulated: How is the effect of technological development on student morality? What are the positive and negative impacts of technical development for students? What can strengthen student solidarity? The purpose of this study is to determine the effect of technological progress on student morality. Know the positive and negative impact of technological advances. Know the things that can strengthen student solidarity. Case study method with qualitative analysis. Researchers conducted direct interviews on students, studying the right books, internet, research-related research researchers, and so forth.
\end{abstract}

Keywords: Influence, Development, Technology, Morality, Student.

\section{A. INTRODUCTION}

Ethics has three roles (Bertens, 2004:14-15), namely: (1) the value system, i.e. values or norms that became a grip for a person or group of people in managing their behavior (Cf., Drejer, 2002:189); (2) the code of ethics, i.e. a set of principles or moral values (Cf., Dwivedi, 2009:389); and (3) the moral philosophy (Babor, 2006:7); the science of good or bad (Sutarno, 2008:10). Social ethics is an Ethic that discusses the attachment or interrelations between individual ethics and its relationship with society (Smith, Mick \& Duffy, 2003:99). Many people are confused and mistaken, because in fact, the social ethics is difficult to separate from individual ethics; ethical individuals are a part of social society (Bradley, 2012: 148). But in this study, the authors focus on the social reality of students.

Pondok Pesantren Al-Ihsan is located at Cibiru Hilir Street, Cibiru Hilir Village, Cileunyi District, Bandung Regency. Most of the residents of Pondok Pesantren Al-Ihsan are students and students of the State Islamic University of Sunan Gunung Djati bandung. Others are students from the University of Education of Indonesia. And there are also studying at Padjadjaran University. The result of the temporary observation, the students who are in Pondok Pesantren Al-Ihsan mostly middle class. Most of them come from West Java, such as Tasikmalaya, Sukabumi, Bogor, Garut, Karawang, Bekasi, Bandung, Ciamis, Majalengka, Kuningan, Cianjur, Sumedang, Purwakarta and Cirebon, and the rest come from another Outside West Java.

Temporary observations made to parse the hypothesis obtained. Namely some of them, santri (students of pesantren) Al-lhsan has smartphone technology and did not have in the early semesters when just stepped on the world lecture. Among the advanced tools are communication tools such as mobile phones, smartphone tablets, notebooks, as well as other advanced communication and information media. Which is a product of modern society. The phenomena observed in their initial entry are as follows: (a) have a cohesiveness in social relationships with santri in one dormitory or with other dormitories; (b) have a high solidarity in a day-to-day relationship; (c) have a considerable amount of communication intensity, such as discussing actual problems, and lecture materials, as well as frequent minor chats. 
Whereas in the beginning, members in the early semester of the room were more numerous, and their heterogeneity was high, and their numbers decreased in the previous semesters due to quitting college, moving to residence, and other things. But the diminishing number of students does not necessarily strengthen their togetherness. Relationships as students who live in the same fate-even looks stretchable. Even after now they stepped on the advanced semester, most of their interaction patterns seem to shift. The shift is as follows: (a) increased cohesiveness, seldom shared discussion, or foreign language training of members of the room; (b) solidarity is reduced, this is seen from the rareness of joint activities even if only a walk to a new place visited; and (c) the intensity of communication is decreasing, even as necessary. They look as though they often ignore and ignore the people around them, and their conferences seem to be given more to what they hold, i.e. smartphones and notebooks, to the impression that they are individualists.

From the phenomenon described above, it is suspected that there is a shift in social ethics that happens to students in Pondok Pesantren Al-lhsan. For that the author tried to research and find out in depth and detail about what really behind the phenomenon that occurred. And focusing on Technology Development (Smartphone) And Its Influence on Ethical Shift, Especially student of final semester of Al-Ihsan pesantren. In order not to be too widespread, the object of the research sample taken will be limited to students from rural areas who have smartphones. As a logical consideration is, students who come from the city though not all of them, have been since childhood familiar with advanced technology. So, the influence on the change of their social ethics established since the beginning between before and after a student with the existence of technology has not too significant.

Shifting social ethics that occurs in the students especially in the Pondok Pesantren Al-lhsan that occurred as a result of the development and progress in the field of information and communication technology one of them smartphones. Differences in their interaction patterns are evident when examined between before and after having a high-tech communication tool. Furthermore, in order that the research done more focused on the specific problem and more focused then the author outlines some special questions: (1) How is the development of smartphone technology and its influence on akhlak-Sufism? (2) What are the positive and negative impacts of smartphone technology development? (3) What can reinforce solidarity?

The purposes of this study are: (1) Knowing the development of smartphone technology and its influence on morality (tasawwuf); (2) Knowing the positive and negative impact of the development of smartphone technology; (3) Knowing that can re-solidarity. The benefits of research is expected to contribute to the scientific influence of the development of Smartphone Technology Against Student Morality. In addition, contemporary praxis is expected to provide a theoretical foundation in an effort to describe the whole and comprehensive about the development of Smartphone technology in Bandung specifically for students who live in boarding son Al-Ihsan. In detail, the objectives and benefits can be highlighted as follows: (1) This study has two uses, first as one part that can be used as a study in the development of science by other researchers in similar or related things; and (2) Presenting the ease for Who want to find out about the development of technology and its influence on the shift of student social ethics.

Socialization is a pattern of interaction is very urgent for humans as the nature of social beings. In this case, the disability in terms of socialization is disturbing for a human person. Although according to Sherif and Hovland (1961) in Teng, Khong, \& Goh (2015), man is not always formed by the situation around him, but humans who form a situation for himself for something that is considered important by him, including in terms of socializing (Sarwono, 2010). Thus, the consciousness of the social actors in interacting using the ethics that are considered sacred (Pensky, 2009:17) and generally applicable is important as a social control (Manna \& Chakraborti , 2010:68) and aims to create a positive and conducive conditions (Carter, 2003:50). In order for no normative law or sanction from the surrounding environment even normative legal institutions often take part as a larger part of the process and are suppressors of the ongoing social relations (Rahardjo, 2010). 
Although socialization is a part of human rights which according to Maududi is a natural right of individuals who are granted Allah SWT, to every human being that can not be revoked or diminished by any power or body (Salahudin \& Hidayat, 2010: 201), but there are normative sanctions that may appear as a reaction of social patterns that are not based on common ethics applicable. Among the factors causing the shift in social ethics are the tendency toward hedonism (Bertens, 2004:235). Many are lulled by all products that facilitate humans in this technology. Epicureus states that hedonism not only seeks bodily pleasures, but in a broader sense is spiritual pleasure (Bertens, 2004:237). The Epicurean states that although all pleasures are good, but not all of them must be utilized as well, He divides three kinds of desires: (a) the natural desire that needs to (eat, drink); (b) the unnecessary natural desire (good meal); and (c) the wasted natural desires (the splendor of wealth) (Bertens, 2004:237).

William David Ross, in Bertens (2004:259) composed a list of obligations (Prima Facie: is the obligation of first sight, meaning a temporary obligation, and only valid until the obligation arises that is more important than it. As lying to defend the faith takes precedence over telling the truth but harm our friend. Honest to say is the first obligation that includes prima facie]): (a) the obligations of faithfulness; (b) the indemnity obligations; (c) the obligations of thanks to those who do good to us; (d) the obligation of justice; (e) the obligation to do good; and (f) the obligation to not harm others, We must not do anything harmful to others (Bertens, 2004:260). One of the things that can be an indicator of the pattern of social ethics of society, especially students is to make observations around us directly and thoroughly.

So as to produce the hypothesis obtained from the result of dialogue between our hearts and minds that are gained from knowledge based on our experience. From the hypothesis is concluded that there is a pattern presented William David Ross partly no longer used by the students in their association. Then do more in-depth research and to the object in question. So, the results obtained answers about how the actual shift of social ethics that occurred. And want to know how the reality of the condition of the object concerned when doing the process of interaction with the invited to interact. And what motivates the students to always keep the ethics.

The indicators of technological development and its effect on student morality shift can be known through some emerging phenomena. Among them (1). There is a contrast between student interaction patterns between before and after having advanced communication tools. (2). There appears to be a significant difference from the students concerned when interacting before being busy with new technology and after being preoccupied with the new technology they already have. Based on the above theory, the influence of technological development is allegedly becoming one of the causes of student morality shift. For that the researcher would like to research further and detailed about "Influence of Smartphone Technology Development to Student Morality".

\section{B. METHOD}

To collect, compile, and detail the research data using the following steps: 1. Determining the location of research This research was conducted in Pondok Pesantren Al-Ihsan, Cibiru Hilir Street, Number 23, RT: 01 / RW: 02 Village Cibiru Hilir District Cileunyi Bandung regency. The things that the author takes the place is referred to sebgai follows. a. The location is available data source needed for research $b$. The location is considered relevant and representative with research conducted c. The location is easily accessible because geographically the author considers that the location in question is quite strategic and close.

\section{Determining the type and data source.}

The type of data used in this research is the type of qualitative data. Data obtained from the results of direct observation and interviews against the targeted research object. The data obtained from the observation and the interview is the objective condition of the observation location. The reality of social 
patterns that occur in students who have advanced communication and information technologies that affect their morality. Sources of data used in this study are primary and secondary data sources. The population that became the source of research data is the student boarding son Al-Ihsan last semester who has a smartphone and come from the countryside. The primary source is the result of interview data obtained by researchers from respondents. As well as additional data in the form of information related to the topic of research, either research other sources, or from the internet.

\section{Determining Research Methods.}

Researchers using descriptive method of analysis in research conducted. Because the problem to be studied is a factual problem and occurs in the present. In its application researchers not only describe the data in detail section. But more deeply with the analysis so that obtained results that truth can be justified. The data in the form of data observations of phenomena that occur and the results of the answers obtained through direct interviews with respondents, namely students who are in boarding school Al-Ihsan, Bandung.

\section{Data collection techniques.}

Data collection techniques conducted by researchers in this study include: (a) Observation: Data collection is done by direct observation. That is by observing various processes and activities of student interaction phenomena that occurred in Al-Ihsan Pesantren. In addition, the authors also observed directly interaction patterns that occur in students, especially emphasized when they are busy each other using their communication tools or gadgets. So, obtained how the suitability of ethical principles in general on the phenomenon that occurs. With the observations made, the writer's hope is to get a direct picture of the students' mental attitude while co-existing and busy each other using modern technological products resulting from the progress of the times; and (b) Interview: Researchers conducted direct interviews on respondents to obtain complete and detailed research results. Among others are the students at Al-lhsan dormitory last semester who have smartphones as communication and information technology is quite sophisticated. All aims to collect data about the effect of technological development on student morality shift. The author is searching.

\section{Data analysis.}

All data that have been collected further as a whole are analyzed in accordance with the data group. Whether it's primary data, or secondary data. To analyze and detail the data of observation and interviews that have collected authors using qualitative methods. The steps taken are: (a) Collecting and compiling necessary data; and (b) Drawing conclusions; with the comparison between the reference theory and the reality that occurs in the field, it can be obtained the results of the assessment on the data, whether relevant to the theory, the theory of the researcher reference, there are some relevant to the referral, and some are irrelevant.

\section{RESULT AND DISCUSSION}

The results of research are: no one has examined the influence of the development of smartphone technology to the morality of students. The research of previous researchers named Atun Bayyinah. He discussed the Ethics as well. But with a different title, namely "Ethics Working Modern Society (Case Study on Employees Pusdiklat PT Krakatau Steel Cilegon Banten)". Using interview methods on all staff sections in the organizational structure of the premises, from managers, other employees. While the researchers want to present is "The Influence of Smartphone Technology Development to Student Morality". With the same method of interviewing the intended respondent. Respondents who the researcher tuju is student / santri Al-lhsan boarding son, final semester. So, the object and focus that the researchers do is not the same as that done sister Bayinah. Another study at Al-lhsan boarding school 
which discusses "Pesantren organization culture (Case Study Organization of Al-lhsan Pondok Pesantren, Bandung)" written by Muhammad Sari. Thus, so far, no similar research on "The Influence of Smartphone Technology Development on Student Morality" in Al-Ihsan boarding school. So, researchers intend to continue the research and writing of the theme that has been submitted for research writing in Institute Penelitaian and Service to Society UIN Bandung this.

\section{The Impact of Smartphone Technology Development on Morality.}

In today's modern age education is needed. Education is needed to improve the quality of the individuals who get it. There are so many jobs that require someone who wants to work in them to have a certain level of education. Call it companies that require professionals such as corporate managers, marketing, even in the academic world though. A person who wants to become a teacher must have a certain degree of education. Likewise, lecturers and others have to lecture first. Someone's goals vary.

When I ask students: What is your college motive? Zulmi replied: "My college motive is because my ideals become a teacher or a lecturer, so I have to go to college. Want to be different with my family. I want to be a teacher. My goal is just because I want to be a teacher. If the concept of religion is only as knowledge ". Jamil replied: "To raise the social strata in the family. More appreciated people, enriching intellectuals of science ". Ipan replied: "The reason is to study science, my career, and for family". Lutfi replied: "My college motive is to seek knowledge, insight, experience, and the demands of the times. As a man must have provisions to live happily in the future and for family happiness ". Abdul replied: "My college motive is to improve my standard of living in education.

We know that education is very important ". Of all the answers to questions that authors propose about their motives to study, almost the whole is a category of utilitarianism. That is all things that are useful things that have a purpose. Utilitarianism has a characteristic that is: The good bad principle according to utilitarianism is the size of the benefits of an action. The purpose of life is perfection in quality and quantity. The goal is the happiness of many people. Sacrifice is considered good if useful. The person of utilitarianism is John Stuart Mill (Lyons, 1997).

Luthfi is one of those who hold hedonism. Hedonism has a characteristic: Good bad measure is the act that results in pleasure. Man, always desires pleasure. Hedon flow figure is Epikuros, states there are three sources of delicacy. a). reasonable delicacy is needed once (eat). b). reasonable delicacy that has not been needed once (good food). c). Unnatural delicacy that is not needed and felt by man because of the wrong mind base (the splendor of property) (Cf., Sudarsih, 2011).

From the above interviews about college motives, most of them have strong economic motives, as well as other world interests. While the religious aspects tend to be set aside. Though the authors hold that all human actions should backed by religious motives. Because religion provides clear rules as a guide in doing good in life (Cf., Talevich, Read, Walsh, lyer, \& Chopra, 2017).

Religion also gives value about non-sensory aspects such as consideration in behaving so as far as possible not to offend and offend people we wear action. In order not to appear misunderstandings that led to disputes. The motive of improving the quality of life to meet the demands of the times and work in the future is indeed the most natural and logical thing. But behind it all there is a deeper meaning that is more fundamental than just those motives. That is the purpose of studying science is one of the commands of religion. So, in the end if we do the search of science with sincerity and patience, then we will get reward by God Almighty.

Facility is one of the supporting for the success of someone studying science. Whether it's a place to live, easy access to the place of learning, and so forth. It is undeniable that the circumstances of the living environment can affect a person's learning. Although in fact many of the students who are able to adapt to the surrounding environment in a short time. From the interview results, the authors ask: What is the condition of your place of residence? Zulmi replied: "The condition of Al-Ihsan for me comfortable fun, 
thank God, although initially did not want in boarding, but because the demand "bidikmisi" (government affirmative action for special students) so I just wrote, I am easy to adapt, so happy and comfortable". Jamil replied: "Conducive. When studying, sleeping or eating, he said "alhamdulillah" running conducive because santri in the room 1 is diligent in their respective scholarship ". Ipan replied: "The condition in which I live is quite comfortable" Luthfi replied: "The condition of my dormitory in Al-Ihsan is quite comfortable for the students, although there are many complaints about it, the pesantren is not comfortable, if the pesantren is so simple. It is "Abdul replied:" I live in pesantren al-Ihsan, the condition is conducive, the environment is all students and students so very supportive of teaching and learning process and we can exchange information to different friend majors (Interview, July 2017)." Most of the respondents stated that their current residence is quite comfortable. Zulmi is a fairly adaptable person. Jamil and Ipan too. While Luthfi more complained with the situation that felt full of shortcomings. But in the end, he tried to accept the state of the pesantren. The author argues that we should try to be concerned in any circumstances, especially when studying. The author also holds to a thought that states that will not succeed a science prosecutor unless he goes through it with great concern. Therefore, we should not complain much.

In addition to the means of residence, supporting student education in modern times is technology. Technology that contributes great in supporting education is information and communication technology. With information and communication technology that can be accessed through smartphone, the students are able to easily get knowledge about all the things needed. Good for college references, or just another general insight. When the author asks: How important is communication technology for you? Zulmi replied: "Technology is very important. Our modern age cannot be separated from it. All needed for college assignment info, campus info, from Face Book, Smartphone, so very important ". Jamil replied: "Urgen really. Because intellectuals are inseparable from electronic devices. We can die style. For the task too ". Ipan replied: "Communication and information technology is very important for life, especially supporting education and socializing with others". Lutfi replied: ". Technological urgency is very important. Both transport and communication technologies are essential. Sometimes asking for an appointment with a lecturer also requires initial communication first, yes, I use the smartphone. We also go everywhere using technology. So very important ". Abdul replied: "That's right. Because after all the environment greatly affects the attitude of a person, from village to city there is such as social change. Where in the village had been living in mutual assistance, when to the city, then the individualist affects the life of a person. Suppose in association, speaking, and thinking " (Interview, July 2017).

From the above interviews, all respondents stated that information and communication technology is very important to support lectures. In addition, it can access any information easily, and quickly. Another function is to just be stylish. Anyone who uses them to make agreements and disseminate information. Whether we realize it or not, many aspects change in students, the change is very likely to happen to students from rural to urban areas, or urban people. Especially the difference in attitude between still be a student of the early semester and become a student of the final semester.

For a change in social attitudes, the writer asks: A person who moves from village to city mostly changes in his attitude of socializing with the community. Is it right? Zulmi replied: "Yeah, right. Sometimes the villagers are katro (countrified), quiet, then transformed into modern, active, due to environmental or group demands, to gain recognition from the group, and to exist personally. " Jamil replied: "It depends on the person. If the character he is able to defend, then he will not change, as I am able to filter everything. Ipan replied: "Yes, really, very often their social attitude changes." Lutfi replied: "Yes, most people who used to be from the village tended to change. Negative side sometimes egoism master, prestige to mingle with people of kampong, less gotong royong and tolerance. In the complex city is blocked, so the individualism is thick. While the interaction in the village is more intensive ". Abdul replied: "communication is needed today. Because it can connect us with people in the world " (Interview, July 2017). 
From the interviews of the authors with the respondents, almost all of them stated that there was often a change in social attitudes toward the students who came from the village and settled in the city. Others say everything depends on the individual. If the individual has a strong character then his attitude will not change. However, most of the phenomena, and the experiences of the respondents, show that more changes are happening to urbanites. Changes in urbanity due to several factors. Among them is the demands of the community or the group that requires him to change. Then the urban environment conditions tend to be individualistic, and rarely work together. The condition of urban buildings tends to be partitioned, thus reducing the intensity of communication between neighbors (Jetten, Postmes, \& Mcauliffe, 2002). Advances in technology, and so forth. And they should not change in an ethical manner. Especially if they know the good teachings in religion that gives the advice of doing good to fellow creatures of God.

Researchers ask: Have you treated and responded well to your friends while using your smartphone as you did not use it? Zulmi replied: "Same thing. I'm not very focused, so I respond to everything well. Some like to focus on hp, but I like to be placed first ". Jamil replied: "I admit sometimes we use our cool gadgets with their own world. Impressed autism times yes ". Ipan replied: "I always try to respond my friends well when I use my smartphone". Luthfi replied: "If I focus too much on smartphones, sometimes I do not really respond to my friends. But I also never lend it to my friend. If again focus on his smartphone ". Abdul replied: ". I do not think so. Because sometimes if we are focused with a smartphone that we use the question of a friend less enter our brain, so the response is late, or less " (Interview, July 2017).

Most respondents replied that they were always trying to respond to friends around them even when using a smartphone. Although there is also a claim that sometimes less respond to friends around, and vice versa, friends around like to ignore the other. Ignoring our friends because we are too focused with smartphones including less ethical actions. As the results of interviews with the authors of the respondent: Do you think not respond well your friends while using a smartphone including deeds that are less ethical, or not related to ethics (immoral)? Zulmi replied: "No, because suppose there are people who want to communicate, we continue to not respond to the person then we seem to forget the person as a human". Jamil replied: "It could be some possibilities. Because of us sometimes are really cannot be disturbed. Unethical if we just update status ". Ipan replied: Unethical, because I think when we do not treat our friends well is unethical, even if we are focused with our smartphones. And do good to friends is obligatory". Lutfi replied: ". Actually, it's not ethical. But both are also needs. Whether using a smartphone or direct communication with a friend is a necessity. Although it is unethical to cheat on friends ". Abdul replied: "Honest is not ethical. Because we can say we are less sensitive to our environment. But on the other hand, if we are focused on something more important, our friends should also want to understand our situation " (Interview, July 2017).

From the interviews of the authors, it is known that most respondents stated that ignoring friends when we are busy with a smartphone is an action that is less ethical. It can also be called immoral action, (Bertens, 2004) which is immoral. There is also a reason that ignore friends are also sometimes because there are other things that are considered important obtained from accessing the smartphone. So have to ignore friends who are there beside for a while. Ipan includes people who always feel obliged to respond well with friends. The author agrees with the Heidegger's view that speech is a humane, fundamental activity that becomes a way for people to express their experience, "to be together" with each other (Mierson, 2003:12-13). However, the authors view that direct communication with friends of people around should also be a concern that should not be ruled out. Because basically when we communicate with smartphones to other friends to strengthen our relationship, it will be better if our communication with people around us was well preserved. Of course, still the point is the willingness to try to do good to sesame sesua religious ties that we embraced in ethics.

\section{Morality Shift}


The author asks: How do your views generally assess your behavior when using a smartphone? Is it good or not? (Common normative ethics), what sometimes do you regret it? (Conscience prospective, retrospective) (shame culture, guilt culture). Zulmi replied: "Smartphones sometimes become their own constraints, e.g. again busy themselves in their own rooms. Certainly, if the night is also in their respective busy rooms. If the other play their smartphone, so I go. Sometimes there is a sense of regret if I do not respond to friends. But how else, especially if busy with our activities, but our regret is not shown directly. Sometimes we also do not like to see friends who are too focused to smartphone ". Jamil replied: "Sometimes we position it as an object ignored, we are emotional. I as an object also sometimes sorry, and friendship becomes tenuous ". Ipan replied: "I am behaving to people depending on who I am dealing with. If the person is important, then I will take seriously, but if not, then I will not take it seriously. Sometimes I regret if I ignore my friend ". Luthfi replied: "I do not tend to focus too much on gadgets. The person who should take precedence is the people around us. Sense of regret is also there if we ignore the friends. It makes us hurt too make us uncomfortable ". Abdul replied: "Sometimes when we use smartphones, we are less responsive to friends. But sometimes if the question is less important I do not respond. I like to regret my less ethical deeds " " (Interview, July 2017).

In interaction is often a misunderstanding. From the misunderstanding that happens, sometimes we who feel the cause of the conflict feel sorry. The heart feels uneasy before the problem is resolved. In ethics called Same culture is a culture of shame and unknown guilt. While guilt culture is culture mistakes. Shame culture prioritizes self-esteem, good name, prestige status and so on. Shame culture masked all the actions that would embarrass her if she found the worth worthy. So, there is no conscience in shame culture. Sanctions on shame culture come from outside. Another case with guilt culture. In this view when someone makes a mistake, then he will feel guilty, and regret his actions. Conscience participates in guilt culture. Guilt culture sanctions are on the conscience (Bertens, 2004). Most of the respondents who felt they had ignored their friends because they were engrossed in using a smartphone claimed a regret. This means that the culture of guilt culture or regret and guilt still suffice for the students.

The researcher asks: Do you think your actions are natural and happen by itself, or are they influenced by something other than yourself? (Natural and moral necessity) Zulmi replied: "What I experience, I do to the environment is based on community environmental factors. The environment urges me to ignore the theme-friends. Jamil replied: "Natural. I person if it is cool with one thing, yes forget everything ". Ipan replied: "Yes, I did my communication naturally, I was not made up, so I feel comfortable with myself". Luthfi replied: "The factors that affect my behavior naturally do not realize conscious. When using my smartphone indirectly influenced social media news ". Abdul replied: "Obviously something is not natural. My actions are driven naturally, and the environment" " (Interview, July 2017).

From the questions, authors propose about moral imperatives, most of them claim their actions in responding to their friends are natural, not artificial. Except for Zulmi, he argued that everything he did was based on the circumstances of the environment that forced him to do so. He was carried away cool with a smartphone while seeing friends around fun with smartphones.

From the description above, it is known that most respondents answer all questions or respond to their friends around with the necessary when using a smartphone. The language used is shorter. Though the language provides the widest possibility to establish social relationships, store and spread information, especially related to the development of civilization and culture (Ratna, 2013:260). Both use constative language, (Kaelan, 2009:141) (describing factual circumstances) or others. The majority of their way of speaking is shorter than it should be when they are not using a smartphone. They tend to focus with their respective smartphones. So, there is a change in their social attitudes verbally. Habermas stated that communicative action is the use of certain language toward the achievement of understanding. Achieving understanding is the process of reaching agreement between the subject that speaks and acts (Mierson, 2003:25). 
Researchers ask: How is your action different from interacting with your friends around when you focus with smartphone? Is there any difference pattern in your language either short or so? (Metaethics) Zulmi replied: "Clearly different. If again use a smartphone, any answer as necessary. But again silent, or do not use smartphone then our answer more diverse, communicative, hold smartphone, we are asked a can answer a, but if not hold smartphone, we are asked a, can answer abcd .... etc". Jamil replied: "The difference when I am without my gadget can be more straightforward to talk at length, inversely with when using it". Ipan replied: "I often briefly answered friends' questions around when I was cool with my smartphone". Luthfi replied: "Yes, sometimes I answer as necessary because it is too focused on the same gadget. And focus on social media outside. So maybe our friend likes to be the victim. And I think that's common, and most people have smartphones. " Abdul replied: "Sometimes when we concentrate with a smartphone different from when not using it. Sometimes our language is shorter, communication is clearly reduced because we focus on smartphones" " (Interview, July 2017).

From the description above, it is known that most respondents answer all questions or respond to their friends around with the necessary when using a smartphone. The language used is shorter. Though the language provides the widest possibility to establish social relationships, store and spread information, especially related to the development of civilization and culture. Both use constative language (describing factual circumstances) or others. The majority of their way of speaking is shorter than it should be when they are not using a smartphone. They tend to focus with their respective smartphones. So there is a change in their social attitudes verbally. Habermas stated that communicative action is the use of certain language toward the achievement of understanding. Achieving understanding is the process of reaching agreement between the subject that speaks and acts. Karl Jasper (1941) states: "the truth of philosophy views all human beings as another possible, which is our duty to stay in touch with them". The human duty is to communicate with others. There's no reason to avoid it. If you think you know the truth, then you cannot just leave the communication (https://www.marxists.org/reference/subject/philosophy/works/ ge/jaspers.htm).

To the authors agree with the statement jasper stating that communication must be done and cannot be avoided if we do feel that we are human beings who know the truth. The author asks: Do you sometimes use your smartphone to annoy your friends? Zulmi replied: "Never bother friends with smartphones. I have never used it for the purpose of harassing others ". Jamil replied: "Often, sometimes at 12, I stay up with a fast music. I'm sure my friend is disturbed". Ipan replied: "I do not think ever". Luthfi replied: "I do not tend to be so. I use a smartphone to open the media. I do not think it disturbs anyone. I use gadgets for business as well. There is a business group that I cannot mention. " Abdul replied: "Yes. Sometimes if I use a smartphone cannot be circumvented that there are parties who are harmed. If there is a friend who asks for my help not direct response. It also lacks response to friends ". From the description above, it is known that most of the respondents did not disturb his friend. Except Jamil. Jamil often uses his smartphone and laptop to play in the middle of the night so it interferes with his friends. So, it can be concluded that some of the respondents adhere to the limits of freedom, namely environmental freedom which other people also have the right to get peace.

Researchers ask: Do you often feel compelled or unwilling to comply with a request or answering a friend's question around you, while you are engrossed in playing with your smartphone for games or social media? Zulmi replied: "Very often. When we are cool with something, or with smartphones for Face Book or other when we are again fun, comfortable, we do not want to be disturbed ". Jamil replied: "Depending on the mood, if I do not want to be disturbed I'm angry. If I just play games I do not feel disturbed ". Ipan replied: "yes, sometimes I do not really like to be disturbed when using a smartphone". Lutfi replied: ". When I was engrossed in a smartphone I always tried to stop my smartphone or put it off. I give priority to friends around me first ". Abdul replied: "I've felt it. It must happen to everyone. Anyone whose pleasure is disturbed, then there will be anger at the person ". From the question that the authors propose, it is known that most respondents expressed dislike interrupted when using a smartphone. They 
tend to feel cool about what they are using. Except Luthfi, he always tried to delay his smartphone when someone talked to him. But not so with other respondents.

The author asks: How do you address the news in social media or something else? Do you find out the certainty first before being / commenting, or what kind? Zulmi replied: "If there is any info that, I understand first, not too deep as well. But sometimes if there is gossip likes directly delivered to people ". Jamil replied; "I saw the news, I did not find out more, and did not search again, nor commented. Ignorant". Ipan replied: "Yes, I always try to find out the truth news in social media, and then dare to comment". Luthfi replied: "Yes, it is clear I find out first the truth is not from one media. So, the truth is clear. If only look at one media, we will have indoctrinated by the media if the info is swallowed raw ". Abdul replied: "I feel the news depends on the news. As a law student sometimes must be once sensitive to updated news. But I do not want to harm me with my attitude, I find out the truth before behaving ".

From the researcher's question to the respondents, most of them tend to trace the news first, so understand it. Like Lutfi and Ipan. Jamil tends to be less concerned. Whereas Zulmi tends to immediately spread all new news. So most do not violate social ethics in social media. Researchers ask: Do you always keep the promise and loyalty, and have a good response, just as you before having a smartphone? Or does it feel something has changed in your point of view? Zulmi replied; "nothing has changed". Ipan replied: "Yes, I always try to keep my promise to my friends whatever the condition". Jamil replied; "Same, sometimes I break the promise but do not give news. Of course, because there is something urgent, but can directly provide info ". Luthfi replied: "On the promise I clearly prioritize my promise for personal and group interests. I have not changed ". Abdul replied: "Promise and faithfulness must always be kept. My principle of trust is more than money ".

From the description of the answer above, nothing has changed in the attitude of fulfillment of the promise. Jamil reneged on the promise if there is a more important need. But he still tells the person concerned. So that ethics keep the promise is still awake. Like a pearl word, "promise is debt". The promise should be done as much as possible. So that not many people we promise to feel disappointed and make them less trust in us. Religion also gives much advice about fulfilling promises, and people who renege on promises do not belong to good people. Habermas states that communicating is making our desires understandable, not pursuing the fulfillment of desire as soon as possible (Mierson, 2003:29). So even if we're using a smartphone, that does not mean we have to fulfill the desire to use it all the time, but there are certain times that we use to meet other demands that we know to know and understand. The author asked: Do you often use smartphones during college hours? Zulmi replied: "Situational hell, I use a smartphone if class is boring". Jamil replied: "Sometimes. Looking at a saturated lecturer, then watch a video, music, or online ". Ipan replied: "Yes, I often use smartphones during college hours". Luthfi replied: "I rarely access the smartphone during college. How do we concentrate on the lessons if focusing on a smartphone ". Abdul replied: "I use it often. I am just idle or bored. Sometimes told by lecturers for new knowledge ".

From the question the authors propose, the respondents mostly use their smartphone during college hours. Of course, if viewed in terms of ethics, the act is considered less ethical. For violating one of the student interaction ethics described in chapter two, i.e. not using a mobile phone during class time. Logically, as we study, then focus on other things beyond our study, then our predecessors on what is taught will not be maximized. So, we should not use the smartphone during the lesson. As stated earlier from Habermas's opinion, communicating does not mean to fulfill the desire as soon as possible. So when learning, should we delay the desire to use the smartphone first.

The author asked: Do you sometimes forget your routine for being too cool to use a smartphone? (Do not do other hobbies) Zulmi replied: "Often, one of them if again fun of Face Book or BBM, sometimes, if they do the night prayers. they also like to be missed". Jamil replied: "Often. Sometimes forget to bathe, eat, sleep, luggage play smartphone, new laptop ". Ipan replied: "No, I always do my routine even though 
I have a smartphone". Luthfi replied: Yes, one side using the smartphone so additional routines. Not that it forgets others because other activities keep going ". Abdul replied: "I I often forget with other activities because of cool, or chat with friends". From the description of respondents' answers, Jamil and Zulmi tend to often leave the routine because of the smartphone. Zulmi sometimes missed his worship time. In contrast to Luthfi and Ipan who tend to consistently perform routines as they should. Habermas states that what is harmful is the possibility of loss of humanity texture on the part of our lives. Systems and the world of life are not in pairs, systems live by their own power. If people give their lives to the system and others, the less life can be explored from dialogue where one seeks to be understood by others, and to understand the others. Habemas in Mierson (2003:35-36) says there is an extensive divide between system integration and social integration. System integration is where the people in it are unified by a number of common procedures and rules. Social integration where people come together thanks to a common understanding that they maintain their sustainability. The author agrees with Habermas's view. The smartphone's communication system does make one override social integration. So, the routines that take place involving the motion of worship and communication becomes less intense even forgotten. We should hold fast to our religious suggestion in maintaining good relationship with god and fellow creatures.

\section{Positive and Negative Impacts.}

The development of information and communication technology has a positive influence, such as the results of interviews of the authors to the respondents as follows: the author asked: What are the positive and negative impact of advances in information and communication technology? Zulmi replied: "Positive We can get updated info from outside that we do not know at all. Enrich knowledge of social media or other, communication is also easier. The negative, the smartphone makes us alienated with our neighborhood friends. Sometimes if overload information on the internet, if we do not select it can be viruses ". Jamil replied; "Positive. Reunite friends who are 7 years old do not meet in pesantren. Unite the long-standing relationship breaks. Working on tasks, fast remote communications. The negative is I often open the site forbidden, so able to see the site ". Ipan replied: "The positive impact is we can communicate quickly, with technology literacy also we can avoid the negative impact. We like the synonymous with our smartphone application, reduced socialization directly with friends". Luthfi replied; "Positive: mostly positive impact. But it depends on the person using it. Suppose in google play store many educational support applications. Entertainment also, negative impact yes there is also a google play store app which is negative because of the ease of access to the media ". Abdul replied: "something is flanked by two effects, positive and negative. Its benefits can unite us with other humans around the world, and add to the insight of knowledge, the negative is the interruption of our social interactions. Sometimes friends in addition we also contact through social media, line, and others, but close really "

\section{Positive impact of information and communication technology:}
a. Obtain the latest information.
b. Get information from social media.
c. Simplify remote communication, anytime, anywhere.
d. Connecting the long-lost relationship.
e. Work on assignments and get referrals.
f. Getting a lot of very useful positive apps (Mierson, 2003:60).

2. Negative Impact of Information and Communication Technology Development of Smartphones
a. Feel alienated with friends.
b. Easily accessing illicit sites that affect our behavior.
c. Addiction app on smartphone. 

d. Reduced intensity of direct communication with friends.
e. It is easy to get an application that can ruin morality.
f. The emergence of computer viruses (Mierson, 2003:58).

The author is in line with Habermas's earlier view, which states that communication systems sometimes override social integration. So, the negative impact of a systemic smartphone communication system is one of them is to reduce social integration between the subjects who use it. "Mobile phones will be an omnipotent medium for bringing all the surrounding things into the system, getting rid of processes for reaching understanding, replacing meaning with messages, changing agreements with orders, and changing understanding with information. In that process the world will be displaced, we will be abandoned, coordinated but not connected, in the network of shared systems to work and gather together, finally what happens is "the technicalities of life" (Mierson, 2003:60). While maintaining social integration is an important thing worth doing, in order to create harmony in social relationships. Religion also encourages many people to always do good in relation to fellow human beings, keeping it with full sincerity and responsibility, so that the value of worship separately.

\section{CONCLUSION}

Based on the discussion and research that the author did in the previous chapters, it can be concluded that: Ethics have a very important role in human life. Ethics governs all human behavior so as to establish communication and harmonious relationships in life. Ethics as a benchmark for the good of one's actions has a close relationship with the teachings of religion that both regulate the behavior of human beings. Most of the students of Pondok Pesantren Al-lhsan have motives that tend to utilitarianism, i.e. the idea that everything is considered good if it has a purpose. The principle of good living is that which reaches perfection of quality and quantity.

From the observations made by the author, found a change in the way students interact. Differences in social behavior occur especially when students focus on their advanced communication and information technologies. Most of them are not able to balance attitudes toward the technology they have, with whom people are around. Some of the students feel cool with their own smartphone rather than socializing directly with friends around him. Technology does not fully have a positive impact on humans. In social ethics, for example, technology has a negative effect on humans. Some things concerning social ethics are neglected due to the influence of technology for their owners. Suppose that student interaction ethics should not use smartphones in college. Then metaethics or language ethics are ignored in responding to people around by speaking very briefly and appropriately. Next is the decrease in direct interaction with friends around different from before when not having advanced communication technology.

Technology also causes some students to leave their routines like worship. However, there are still strong aspects that are not affected by technological developments, i.e. the students tend to keep their promises. Respondents agreed that their greatest motivation to always do good or to be ethical towards those around them was because of religious motives. They all agree that doing good is a worship that has its own value before God Almighty.

Based on a general description of the study authors technological developments and their effect on students' social ethics shifts that occurred in Pondok Pesantren Al-Ihsan Cibiru Downstream, Bandung, the author gives some suggestions as follows: (1) with the evident shift in social ethics students who have Smartphones, should have a sense of tolerance and attitude to be more willing to improve themselves to the environment to maintain harmony in social relationships; (2) Trying to minimize the negative impact of the development of information and communication smartphone technology; and (3) Always maintain 
and establish activities that are considered able to strengthen solidarity among friends so that social ethics and solidarity can still be maintained.

\section{References}

Babor, Eddie R. (2006). Ethics (the Philosophical Discipline of Action). Manila: Rex Bookstore, Inc., 2006.

Bertens, Kees. (2004). Etika. Jakarta: Gramedia Pustaka Utama.

Bradley, F. H. (2012). Ethical Studies. New York: Cambridge University Press.

Carter, Matt. (2003). T.H. Green and the Development of Ethical Socialism. Exeter: Imprint Academic.

Drejer, Anders. (2002). Strategic Management and Core Competencies: Theory and Application. Wesport: Greenwood Publishing Group.

Dwivedi, R.S. (2009). A Textbook of Human Resource Management. New Delhi: Vikas Publishing House. Jaspers, $\quad$ Karl. $\quad$ (1941), $\quad$ On $\quad$ My Philosophy. https://www.marxists.org/reference/subject/philosophy/works/ge/jaspers.htm (accessed 31 July 2017)

Jetten, Jolanda; Postmes, Tom; \& Mcauliffe, Brendan J. (2002). 'We're all individuals': group norms of individualism and collectivism, levels of identification and identity threat. European Journal of Social Psychology. 32, pp. 189-207; https://dx.doi.org/10.1002/ejsp.65

Kaelan. (2009). Filsafat Bahasa Semiotika dan Hermeneutika. Yogyakarta: Paradigm.

Lyons, David. (1997). Mill's Utilitarianism: Critical Essays. Lanham, Boulder, New York, and Oxford: Rowman \& Littlefield.

Manna, Samita \& Chakraborti, Suparna. (2010). Values and Ethics in Business and Profession. New Delhi: PHI Learning Pvt. Ltd., 2010.

Myerson, George. (2001). Heidegger, Habermas and the Mobile Phone. Cambridge: Icon-Totem, pp. 1213

Pensky, Max. (2009). Ends of Solidarity, The: Discourse Theory in Ethics and Politics. Albany: SUNY Press.

Rahardjo, Satjipto. (2010). Sosiologi Hukum. Yogyakarta: Genta Publishing.

Ratna, Nyoman Kutha (2013). Paradigma Sosiologi Sastra. Yogyakarta: Pustaka Pelajar.

Salahudin, Anas and Hidayat, Heri. (2010). Civics Education. Bandung: Gunung Djati Press

Sarwono, Sarlito Wirawan. (2010). Teori-Teori Psikologi Sosial. Jakarta: Rajawali Press.

Teng, Shasha; Khong, Kok Wei \& Goh, Wei Wei. (2015) Persuasive Communication: A Study of Major Attitude-Behavior Theories in a Social Media Context, Journal of Internet Commerce, 14:1, 4264; http://dx.doi.org/10.1080/15332861.2015.1006515

Sherif, M., and C. Hovland. 1961. Social Judgment: Assimilation and Contrast Effects in Communication. New Haven, CT: Yale University Press.

Smith, Mick \& Duffy, Rosaleen. (2003). The Ethics of Tourism Development. London \& New York: Routledge. 
Sudarsih, Sri. (2011). Konsep Hedonisme Epikuros dan Situasi Indonesia Masa Kini. Humanika, Vol 14, No. 1.

Sutarno, Alfonsus. (2008). Etiket, Kiat Serasi Berelasi. Yogyakarta: Kanisius.

Talevich, Jennifer R.; Read, Stephen J.; Walsh, David A.; Iyer, Ravi; \& Chopra, Gurveen. (2017). Toward a comprehensive taxonomy of human motives. PLOS ONE. 12(2): e0172279, pp. 1-32 https://dx.doi.org/10.1371/journal.pone.0172279 